University of Nebraska - Lincoln DigitalCommons@University of Nebraska - Lincoln

Papers in Communication Studies

Communication Studies, Department of

$5-2012$

Selective Amnesia and Racial Transcendence in News Coverage of President Obama's Inauguration

Kristen Hoerl

Butler University, khoerl2@unl.edu

Follow this and additional works at: http://digitalcommons.unl.edu/commstudiespapers

Part of the Critical and Cultural Studies Commons, Gender, Race, Sexuality, and Ethnicity in Communication Commons, and the Other Communication Commons

Hoerl, Kristen, "Selective Amnesia and Racial Transcendence in News Coverage of President Obama's Inauguration" (2012). Papers in Communication Studies. 188.

http://digitalcommons.unl.edu/commstudiespapers/188

This Article is brought to you for free and open access by the Communication Studies, Department of at DigitalCommons@University of Nebraska Lincoln. It has been accepted for inclusion in Papers in Communication Studies by an authorized administrator of DigitalCommons@University of Nebraska - Lincoln. 


\title{
Selective Amnesia and Racial Transcendence in News Coverage of President Obama's Inauguration
}

\author{
Kristen Hoerl \\ College of Communication, Butler University, Indianapolis, Indiana, USA \\ Corresponding author - Kristen Hoerl, Assistant Professor of Media, Rhetoric, and Culture, Butler University, 4600 \\ Sunset Ave., Indianapolis, IN 46208, USA, email khoerl@butler.edu
}

\begin{abstract}
The mainstream press frequently characterized the election of President Barack Obama the first African American US President as the realization of Martin Luther King's dream, thus crafting a postracial narrative of national transcendence. I argue that this routine characterization of Obama's election functions as a site for the production of selective amnesia, a form of remembrance that routinely negates and silences those who would contest hegemonic narratives of national progress and unity.
\end{abstract}

Keywords: critical rhetoric, selective amnesia, transcendence, postracism, Barack Obama

In the introduction to his 2006 book, President Barack Obama wrote that the "flashpoint issues of the Sixties" were "never fully resolved" - that problems of race, war, and poverty have not gone away, and that he was the man to solve them. ${ }^{1}$ In an effort to discredit him, Obama's opponents highlighted his associations with former Weather Underground activist Bill Ayers, and Reverend Jeremiah Wright. While conservative pundits characterized Ayers as a domestic terrorist, Wright was depicted in terms that have been used to describe radical black spokespersons from that era such as Malcolm X and the Black Panthers: angry, militant, anti-white, and anti-American. Rather than deliberate about the purpose of 
dissent, Wright's depiction was leveraged to contain what could be said about race relations during the election. Obama went to some lengths to distance himself from Wright's critique of racism in the United States. During his March 2008 address in Philadelphia, Obama asserted that Wright's rhetoric was divisive and presented a distorted view of race relations in the United States. ${ }^{2}$ Later, Obama commented that Wright's statements were offensive, angry, and bitter. Speaking to the Washington Post, Obama explained that "Reverend Wright remained rooted in the rhetoric of the Sixties ... He never updated or refreshed that worldview to accommodate the changes that were taking place in America." 3

Obama's references to the rhetoric and struggles of the 1960s highlight the president's ambivalence regarding his own political investments in that contentious period in US history. They also exemplify contemporary politics' ongoing struggle over the meaning of the civil rights and Black Power movements that riveted the nation more than forty years ago. Obama's domestic agenda could be legitimated among left-of-center citizens as an extension of 1960s era programs for social justice; however, Obama's platform faced challenges from those who would compare him to contentious black spokespersons who questioned the viability of racial justice within the American political system. Obama's allusions to the antiracist struggles of the 1960s thus managed competing social imperatives to achieve racial justice without substantially transforming the institutional structures that sustain white privilege. ${ }^{4}$

After Barack Obama's election as the 44th President of the United States, press coverage resumed its attention to the civil rights era of the 1960s. However, this time, media commentary honored civil rights' past-Martin Luther King's memory in particular-to convey the significance of President Obama as the first African American President. On the days leading to the inauguration, the press repeatedly underscored the importance of Obama's election through references to King and his 1963 speech at the March on Washington for Jobs and Freedom. The inauguration took place the day after Martin Luther King Day, and Obama delivered a preinauguration address in front of the Lincoln Memorial, the same location where King delivered his 1963 speech. Recognition of King would be expected. More than drawing attention to the time and location of the inaugural celebration, however, these references to King invited audiences to draw particular meaning to Obama's election for contemporary race relations. Allusions to civil rights history across a myriad of reports in mainstream news media positioned Barack Obama's election as the realization of a postracial version of Martin Luther King's "dream" and the culmination of the struggle for civil rights.

These routine references to King and the civil rights struggle in postelection coverage illustrate how popular and political discourse engages the past not only for purposes of commemoration but to put the present in meaningful context. ${ }^{5}$ In this essay, I explain how the confluence of news fragments connecting Obama to King's legacy constructed a myth of transcendence in which the traumas of racial injustice have been overcome. In the process, I aim to extend critical rhetoric's engagement with the concepts of remembrance and forgetfulness in public discourse. I argue that this myth precludes public memory of radical black dissent that has condemned institutional racism in the United States. The narrative pattern that runs across news coverage of the election is a contemporary enactment of selective amnesia. As a corollary to the concept public memory, selective amnesia refers to 
the rhetorical processes by which public discourse routinely omits events that defy seamless narratives of national progress and unity. By attending to selective amnesia in the press coverage of President Obama's inauguration, this essay draws attention to the discursive structures which routinely negate and silence those who have challenged systemic racial injustice in recent US history.

\section{Public Memory and Amnesia in a Fragmented Textual Landscape}

Over the past several decades, rhetorical scholarship has witnessed a proliferation of essays and books foregrounding the concept of public or collective memory. ${ }^{6}$ Much of this scholarship has worked from John Bodnar, who describes public memory as the "body of beliefs and ideas about the past that help a public or society understand both its past and present, and by implication its future."7 Stephen Browne argues that it is the textual quality of public memory that makes it of particular concern for rhetorical scholars. ${ }^{8}$ That is, shared understandings about the meanings of historic events and figures are made possible through their instantiation in public life-through widely circulating or accessible speeches, museums, memorial structures, film, and other forms of popular culture. Outside of the rhetoric discipline, Pierre Nora foregrounds the textual quality of public memory in his discussion of lieu de memoire, or sites of memory, which are deliberately archived or constructed embodiments of the past. ${ }^{9}$

In addition to its textual quality, public memory has rhetorical significance by virtue of its relevance to present historical conditions. Expanding on Michael Kammen's point that societies "reconstruct their pasts . . . with the needs of contemporary culture clearly in mind," Barbara Biesecker writes that "what we remember and how we remember it can tell us something significant about who we are as a people now, about the contemporary social and political issues that divide us, and about who we may become." ${ }^{10}$ Controversies over how particular historic figures and events should be remembered highlight how groups with disparate subject positions hold different ideological investments in public memory. In this regard, sites of memory also comprise sites of struggle and contestation about contemporary politics and national identity. ${ }^{11}$ As Browne notes, representations of the past "assert proprietary claims on the past and hence on its celebration; they will, impose, if not only through sheer repetition, narratives of identity which bracket out certain memories and privilege others." 12 Such selective practices of memory construction have implications for political hegemony. While those who interpret the past are empowered to shape its meaning and significance, differently positioned audiences are often prompted to disregard prevailing social inequities and unjust power relations.

Much has been written about how various public memory sites have appropriated historic racial justice struggles for purposes of legitimating contemporary race relations. Such scholarship has described rhetorical practices by which commemorative structures, ${ }^{13} \mathrm{mu}-$ seums, ${ }^{14}$ presidential rhetoric, ${ }^{15}$ and Hollywood films ${ }^{16}$ have privileged mainstream understandings of civil rights activism and obscured the goals of historical black figures who embraced structural change on behalf of racial minorities. ${ }^{17}$ While Martin Luther King has become an icon for black activism, there are far fewer depictions of figures such as Malcolm $X$ and Stokely Carmichael. In an analysis of the Birmingham Civil Rights Institute, Victoria 
Gallagher observes that Black Power advocates who sought fundamental changes in political, social, or economic arrangements are consistently ignored, discredited, or rebuked in public commemorations to racial justice figures. ${ }^{18}$ Furthermore, references to King have tended to appropriate his rhetoric in ways that suggest racial progress has been largely achieved, ignoring his later programs for racial justice and economic parity. ${ }^{19}$ Kirt Wilson laments that public discourse has not offered a complete picture of what the civil rights movement was or what protagonists did because it has avoided more difficult discussions about the movement's criticisms of racial politics that remain unresolved. ${ }^{20}$ Such observations point to the more troubling implications of selective portrayals of civil rights in contemporary commemoration efforts. Sites of memory designed to remember civil rights consistently simplify, distort, and ignore important racial justice struggles in US history.

Essays critiquing the rhetoric of civil rights and public memory highlight how struggles over public memories of race relations are ultimately struggles over the pitfalls of forgetting racial injustice. Indeed, memory itself is incumbent upon forgetting, as each are essential to the others' existence. ${ }^{21}$ Bradford Vivian notes that the concept of forgetting is routinely subsumed under the concept of memory as the locus of critical interrogation and theory. ${ }^{22}$ As a corrective to this trend, Vivian foregrounds the positive capacities of forgetting for enabling communities to move beyond traumatic conflicts. ${ }^{23}$ Vivian's position echoes Kammen's observation that "memory is ... activated by contestation, and amnesia is ... induced by the desire for reconciliation." 24 Insofar as competing factions in any society must create spaces for reconciliation to move forward, forgetting itself may often be a social good.

Although there may be moments in which past traumas are best forgotten, scholars interested in rhetoric and democratic practice must also interrogate the conditions in which communities are encouraged to forget histories of injustice and dissent. Consistent patterns of discourse that ignore significant events in the history of social and political struggle create an impoverished discursive landscape by depleting rhetorical resources for shared reasoning about public policy, national identity, and social justice. Thus, I suggest that critical rhetoricians should illuminate the symbolic conventions through which marginalized groups and social movements are routinely forgotten in public memory. Although much critical scholarship has attended to the ideological and hegemonic implications of memory work, the concept of forgetting itself has not been elaborated as critical rhetorical concept - that is, as a concept with a formal structure that does rhetorical and ideological work in public life. I argue that the concept of selective amnesia is a critical concept to fill this void, and offer the term to describe a particularly insidious form of forgetting that undermines social justice and collective empowerment.

The study of selective amnesia calls upon scholars to attend to the rhetoric of absence, or what goes unstated within public discourses. As Raymie McKerrow points out, "absence is as important as presence in understanding and evaluating symbolic action." By extension, a study of absence is a fundamental principle of critical rhetorical practice invested in the analysis of discourses of power. ${ }^{25}$ Robert L. Scott has also remarked on the merits of taking up such a challenge, as "silence and speaking both have symbolic impacts and as these become focal, they tend to become rhetorical." ${ }^{26}$ Further, silence may be the most effective rhetoric in the maintenance of existing power relations, as those who would 
seek to challenge prevailing hierarchies may face recriminations for doing so. ${ }^{27} \mathrm{~A}$ study of selective amnesia that I suggest is rooted in Phil Wander's attention to the Third Persona. An extension of Edwin Black's Second Persona, the Third Persona attends to audiences negated in discourse. For Wander, negation includes not just "the summation of all that you and I are told to avoid becoming, but also being negated in history, a being whose presence, though relevant to what is said, is negated through silence." 28 Prevailing prejudices and social injustices call for attention to the Third Persona because the negation of particular groups contributes fundamentally to their subordination. Thus, what is said about members of a society has bearing on their own opportunities to participate in public life. Wander writes, "Operating through existing social, political, and economic arrangements, negation extends beyond the 'text' to include the ability to produce texts, to engage in discourse, to be heard in public space." 29 Working from this framework, I analyze the choices of selection and omission that comprise public memories of the civil rights movement during Obama's election.

In the following analysis, I argue that patterns across mainstream news media coverage of Obama's election constructed a myth of national transcendence in which the traumatic legacy of racial injustice has been overcome. Kenneth Burke describes transcendence as the verbal means of resolving contradictions and reconciling opposites through "a concept of a "higher synthesis,'" 30 that enables the adoption of a new point of view. Working from Burke, James Zappen has recently argued that dialectical-rhetorical transcendences facilitate "communities of interest" that overcome group ideologies. ${ }^{31}$ For instance, when conflicting parties assign incidental status to perceived social violations, they are able to establish new identities and relationships. In this sense, transcendence is a bridging device "whereby one realm is transcended by being viewed in terms of a realm 'beyond it.'”32 Zappen highlights the productive potential of transcendence. In contrast, I foreground the concept's more treacherous implications. I contend that selective amnesia was fundamental to the construction of the myth of racial transcendence. The omission of significant events in the history of antiracist struggle, particularly those events occurring after King's death in 1968, enabled the construction of a seamless narrative that reaches its conclusion in Obama's election. In my conclusion, I discuss the implications of selective amnesia for public memories of civil rights and for contemporary resistance to racial injustice.

\section{The Myth of Racial Transcendence in News Fragments about Obama's Election}

The myth of racial transcendence was crafted intertextually across a myriad of reports which described Obama's election as the realization of Martin Luther King's dream. Such references relied upon postracial interpretations of both King's 1963 speech and Obama's success. I extend my analysis by describing how a variety of traumatic civil rights anecdotes within this coverage found resolution in Obama's election. I continue with an extended example of news coverage that aligns King's legacy with the Obama presidency.

\section{Obama's Election as the Realization of Martin Luther King's Dream}

Oft-stated references to Obama's election as the fulfillment of King's dream provide illustrative examples of how civil rights nostalgia can function as a "rhetorical and political tool 
in the service of presidential image construction." ${ }^{33}$ In the days leading to the inauguration, national print and broadcast media routinely referred to King's 1963 speech as the most significant historic event to give meaning to Obama's election. Reporters quoted public officials, citizens, and former civil rights activists who described Obama's election as the "fulfillment," 34 "embodiment," 35 "culmination," 36 and "validation" 37 of King's dream. ${ }^{38}$ Such commentary appeared in both left-leaning and right-leaning news outlets. On Martin Luther King Day, news anchor David Shuster announced to MSNBC audiences that, "[f]orty-five years ago, the Reverend Martin Luther King Jr. had a dream and tomorrow, it will be realized in a way that many never of you thought you would see in your lifetimes." ${ }^{39}$ That same evening, Former Arkansas Governor and current Fox News channel host Mike Huckabee remarked upon the historic significance of Obama's election, " 40 years after this great leader has passed from us, [King's] dream is, in fact, coming true." 40

In addition to their own commentary, reporters interviewed former civil rights leaders, celebrities, and ordinary citizens who attested to the significance of the election for civil rights. Former civil rights activist Walter Fauntroy told reporters on NBC's Dateline, "Martin Luther King's dream stated 40 years ago we, as a people, are going to get to the promised land. .. . That dream came true on November 4th, 2008." 41 During an interview with Georgia Representative and former civil rights leader John Lewis, CNN's Wolf Blitzer asked what Martin Luther King would think about the election if he was alive today. Lewis echoed Fauntroy's earlier response, "King would have said 'I told you one day that we would make it to the promised land."' Qualifying his remarks, Lewis added, "Well, we may not be there yet. But I think what happened today . . . is a significant down payment on making the dream of Martin Luther King, Jr. become a reality. ${ }^{42}$ For its part, Fox News quoted musician Bono, who told audiences at a pre-inaugural concert, "Forty-six years ago Dr. King had a dream. On Tuesday, that dream comes to pass." 43

Several newspapers and television news programs provided reaction quotes from individuals who traveled to Washington DC to attend the inaugural celebration. These "inaugural pilgrims," as $\mathrm{ABC}$ described them, lauded the election as a civil rights victory. ${ }^{44}$ The New York Times quoted Atlanta maintenance worker Bob Haskins, who told them that the image of college students lined up to vote in the election brought tears to his eyes, "Everything that Martin Luther King talked about is coming true today." 45 USA Today introduced an article with an anecdote from Fae Robinson, who told them she had also attended the March on Washington 45 years earlier. She recalled that as "As she listened to King, she thought, 'Yes, I know what you mean. Yes, I have the same dream. Yes, maybe one day it will come true.'" Then she reflected, "I didn't really think I would be alive to see it, but Obama is the result of that dream." 46 On the evening of the inauguration, NBC's Nightly News program quoted an unidentified woman who recalled her first words to her children after Obama's election, “While you were asleep, Martin Luther King's dream came true.'" 47 Indicating that such statements were not merely anecdotal, CNN reported that two thirds of American-Africans now believed that King's dream has been fulfilled, and that this proportion had doubled during the presidential campaign. ${ }^{48}$ By describing Obama's election as King's dream "come true," these references gave meaning to the Obama presidency as the conclusion to the civil rights struggle. The convergence of political and popular discourse illustrates how patterns across fragmented texts circulating throughout commercial 
media construct a structured symbolic environment that entails particular limitations for interpretation. ${ }^{49}$ These confluences have implications for subjectivity and citizenship. ${ }^{50}$ By depicting Obama's election as the embodiment of civil rights-rather than as an opportunity for public policy on behalf of racial minorities-coverage of the inauguration suggests that protest and dissent on behalf of racial justice is unnecessary.

\section{Postracial Interpretations of King's Legacy and Obama's Election}

Reports and commentary characterizing Obama's election as the realization of King's dream were complemented by comments that advanced a postracial understanding of Obama's success. According to postracial logic, advancements made by individual black Americans are evidence of progress toward racial justice regardless of the overall prosperity of the black community. ${ }^{51}$ By extension, Obama's election signaled that obstacles to opportunities for African Americans had been overcome. For instance, CNN quoted one unidentified woman who stated that Obama's election "gives all of our kids the ability to dream and believe and realize that they can be anything they want." 52 Chicago Sun-Times reporter Mary Mitchell interviewed neurosurgeon Ben Carson about the meaning of the Obama presidency. Carson asserted that "there are no more excuses for anybody." Carson added, "no matter who you are in this nation ... you can rise to the top of whatever it is that you do and that you don't have to feel limited." 53 Carson's quote illustrates how the postracial discourse elicits and extends the American myth of individualism in which people of few means achieve great success through their hard work, strong character, and determination. ${ }^{54}$ Although this myth is most frequently recognized in late nineteenth century Horatio Alger narratives, the myth of individualism has reverberated in contemporary popular media. ${ }^{55}$ Carson reiterates the common postracial assumption that failures toward economic empowerment or success may be blamed on black people themselves; racism can no longer be used as an "excuse" for disparities in income and education. ${ }^{56}$

Postracial discourse surrounding the inauguration frequently engaged King's memory by simplifying King's 1963 speech to the notion of a "color-blind" society. In a Los Angeles Times editorial, former Atlanta mayor and civil rights activist Andrew Young explained his initial support for Hillary Rodham Clinton was rooted in "King's dream" to "elect 'persons of character, vision and integrity' - not candidates of any particular color." 57 During a CNN interview about the legacy of Martin Luther King, singer Wyclef Jean stated that Obama was elected because the current generation "did not believe in racism." Emphasizing his point, he added, "We don't believe in color." 58 Later that evening, CNN quoted former Secretary of State Colin Powell, who remarked that the election was a "tribute to the spirit of Dr. Martin Luther King." He explained King's message was that "people should be judged on the content of their character, and not the color of their skin. ${ }^{59}$ Powell drew upon a well-known passage of King's speech in which he states his hope that his children would "one day live in a nation where they will not be judged by the color of their skin but by the content of their character." By reducing King's message to this particular line, Powell framed the problem of racial injustice in terms of personal prejudice rather than as a structural condition. 
Postracial interpretations of Obama's election in the news media were facilitated by Rick Warren's opening prayer during inauguration services and by Obama himself. In a passage frequently quoted by mainstream print and broadcast media, Warren declaimed, "We are so grateful to live in this land, a land of unequaled opportunity, where the son of an African immigrant can rise to the highest level of leadership. We know today that Dr. King and a great cloud of witnesses are shouting in heaven." ${ }^{60}$ Barack Obama's own rhetoric similarly elicited the memory of King to give meaning to his election as a civil rights achievement. During his preinauguration address at the Lincoln Memorial, Obama proclaimed, "Directly in front of us is a pool that still reflects the dream of a King, and the glory of a people who marched and bled so that their children might be judged by their character's content." ${ }^{61}$ Two days later during his inaugural address, Obama described himself as a beneficiary of the struggle, "[A] man whose father less than 60 years ago might not have been served at a local restaurant can now stand before you to take a most sacred oath." 62 Confluences between Obama's rhetoric and the postracial framing of his election in news media demonstrate how popular and political discourses overlapped and reinforced one another to give meaning to the election as the culmination of the civil rights struggle.

In addition to frames that depicted the election as a civil rights achievement, several news reports suggested that the elections signaled the end to the politics of racial identity. One New York Times article suggested that Obama gained popular support because his campaign avoided "a race-based agenda." The report then quoted African American studies Professor Henry Louis Gates, who described the President-elect as "a postmodern race man." As Gates explained, race was but one aspect of Obama's identity, "He can wear it, he can take it off, he can put it back on.... People don't see him primarily as black. I think people see him as an agent of change." 63 This news fragment complemented the rhetoric of "color-blindness" articulated in other news sources by framing race as a matter of identity that one can choose to adopt or ignore, rather than as a social structure with enduring political and economic consequences.

Paradoxically, two news fragments that challenged reductive comparisons between King and Obama also characterized King's dream and the election in postracial terms. Both CNN and Fox News reported that Isaac Newton Farris, former director of the Martin Luther King Center objected to characterizations of Obama's election as the realization of King's dream. In a brief video clip of comments he had given earlier, Farris asserted that, "[King's] dream was not about an individual or any race of people attaining power. It is a human dream." ${ }^{64}$ This short sound bite reasserted the postracial framing of King's memory by suggesting that King's speech itself transcended racial conflicts. (Despite the intervention, Farris's comments did not deter CNN from repeating the clichéd statements that Farris had condemned. CNN correspondent Joe Johns concluded the report on Farris by stating, "King's hopes taking hold in Obama. And look how far it's come." ${ }^{65}$ )

Few instances in news coverage directly critiqued postracial interpretations of the election. ${ }^{66}$ During coverage of preinauguration events, CNN reporter Soledad O'Brien corrected her colleagues when they described Obama's election in terms of King's dream. Noting that King was fundamentally interested in achieving economic justice for the black community, $\mathrm{O}^{\prime}$ Brien encouraged audiences to develop a more nuanced understanding of 
contemporary race relations by noting, "major social issues that have been problems in this country that have affected disproportionately people of color, Latinos, Native Americans, Asians, African Americans ... ."67 O'Brien's comments received a tepid response as CNN's Wolf Blitzer then turned to political analyst Jamal Simmons to discuss how his grandparents felt about the election, "I'm sure excited," Blitzer told Simmons, "because I've heard from so many grandparents out there, they simply didn't think it would ever be possible." 68 The following day, O'Brien interviewed Cornell West, who also criticized reductionist depictions of King's dream. West asserted that King

didn't want us to be color blind. He wanted us to be love struck. He wanted us to embrace our humanity and to do it in such a way that we focus on poor people, focus on working people, on the precious children, on the disabled, on the elderly, on the widows, those who are often pushed to the margins, not just here but in Asia, in the Middle East, in Latin America.

Given her previous attempt at intervention, it is noteworthy that $\mathrm{O}^{\prime}$ Brien followed her interview with West by asserting that Martin Luther King's dream "was one of an America in which children could be brothers and sisters, whatever the color of their skin." Then she reminded audiences of the results of CNN's poll which found that 89 percent of blacks agreed that the election of Barack Obama "was a dream come true." 69 Fragments such as these indicate that press coverage was not monolithic; however, critical voices such as West's were subsumed by the preponderance of sound bites that distilled a more complex analysis of race relations after Obama's election into a narrative of national transcendence in a postracial era.

\section{King as a Synecdoche for Civil Rights Activism}

The overarching emphasis on Martin Luther King's "I have a dream" speech throughout coverage of Obama's inauguration illustrates how King has become a synecdoche for the civil rights movement in contemporary politics and popular culture. The postracial image of American society after the election extends public policy rhetoric over the past twenty years that has used King's memory to support the idea that race should no longer be considered to evaluate the justice of America's primary institutions. Denise Bostdorff and Steven Goldzwig explain that conservative rhetoric in the Eighties appropriated King's words and memory to justify the dismantling of federal civil rights laws and social programs. ${ }^{70}$ In order to advance a conservative agenda, neoliberal discourse reduced and simplified the civil rights movement and its diverse struggles for racial justice. Furthermore, selective references to King's 1963 speech have obscured the nuances of King's own rhetoric and activism. As Derrick Alrige notes, the tendency for public discourse to focus on the early years of King's activism presents a "heroic, one-dimensional, and neatly packaged master [narrative] ... that den[ies] ... a complex, realistic, and rich understanding" of King's life and his work. ${ }^{71}$

Comments connecting King's 1963 speech to Obama's inauguration drew meaning not just through the articulation of the two leaders, but through the negation of the ideals and strategies that distinguish them. Warren and other media sources that characterized Obama's 
election as the realization of King's "dream" assert an arguable claim about King's own politics to comment favorably upon the election. Although King may have endorsed the election of an African American for President, his ventures in the later years of life suggest that he might have not wholeheartedly endorsed Obama's campaign were he still alive. Following the March on Washington and the passage of the 1965 Civil Rights Act, King was increasingly disillusioned with the possibilities for racial justice within mainstream politics and economics. His antiwar stance and growing advocacy of democratic-socialism suggests that King might have had a complex response to the election of a black man who voiced continued support for sending US troops into Afghanistan and who reaffirmed commitment to working within the liberal capitalist institutions that King sought to change. ${ }^{72}$ The negation of King's own complex legacy thus works to the creation of a depoliticized King.

The propensity to ignore King's controversial stances and reduce his message to a postracial vision of a just society is not a contemporary revision of his legacy. Gary Daynes's analysis of national press attention to King's life suggests that the late activists' public image has always been a rhetorically crafted vision that King himself could not entirely control. ${ }^{73}$ The mainstream print media immediately picked up on his least controversial messages of his 1963 address at the March on Washington to soften the image of civil rights at a time when the White House sought widespread support for the Civil Rights Act. Although the press commented less favorably on King's more radical activism during his later years, they resurrected his 1963 image after his assassination, making him a national hero and symbol of racial unity at a time when riots throughout the country proclaimed an end to the era of nonviolent dissent. Daynes's history of the political rhetoric about King indicates that the reduction of King's legacy as a synecdoche for racial justice was consciously chosen by political leaders and news editors to promote civil rights among mainstream whites and mollify agitated black communities. Thus, recurring references to King's "dream" as one of a color-blind society have endured in public memory precisely because they obscure his more complex, controversial legacy.

That this synecdoche has been used across a myriad of sources that have commented on contemporary race relations in the past fifty years indicates that the use of King-assynecdoche has become a primary resource for shared (mis)understanding about the meaning and role of civil rights activism in the United States. Comments depicting Obama as the realization of King's dream drew meaning not just through the intertextual linkages across textual fragments during the inauguration but also through their resonance to a vast array of similar discourses over the past forty years that invoked King's memory. By limiting references civil rights events and figures to King's 1963 speech, this synecdoche thus delimits the range of rhetorical resources available for attributing meaning to Obama's election or for assessing the implications of the election for contemporary race relations. Postracial suggestions that significant barriers to advancement no longer exist for people of color in the United States ignores persistent racial inequities and new forms of racism that have kept blacks in secondary positions relative to whites despite the gains of the civil rights movement. ${ }^{74}$ Partial and decontextualized references to King's 1963 speech during the inauguration divested King's memory of its potential to address struggles for racial justice that have yet to be won. As the next sections of this essay suggest, news commentary 
about Obama's election also transformed the commonplace in which King's 1963 speech stands in for the broader civil rights movement. By positioning Obama's election as the conclusion to King's struggle, news commentary rhetorically aligned the civil rights agenda with Obama's own leadership, thus suturing the reductionist memory of King's leadership to Obama's public image.

\section{Transcending Traumatic Experience in the Civil Rights Era}

Reports and commentary depicting Obama's election as the realization of King's dream were reinforced and extended through other news fragments that provided brief references to slavery and segregation to highlight the historic significance of Obama's election. Writing for the New York Times, Thomas Friedman commented that Obama's popularity in the former slave state of Virginia "symbolically illustrated the final chapter of America's Civil War."75 Friedman concluded that "the Civil War could never truly be said to have ended until America's white majority actually elected an African American as president." For Friedman and others, Obama's election epitomized America's remarkable social transformation since its days of slavery and segregation.

Broadcast news media routinely interviewed civic leaders and former activists who provided personal reflections on the meaning of Obama's election for the civil rights struggle. These accounts focused on conditions of southern segregation and the early civil rights movement prior to King's organizing efforts in northern cities. In an interview on CBS's Early Show, Newark, New Jersey Mayor Corey Booker mentioned family narratives of segregated restaurants and gas stations. He concluded that Obama's election was a national accomplishment and the "culmination of the struggle and the sacrifices of generations."76 On Martin Luther King Day, Congressperson John Lewis spoke to NBC Nightly News audiences about the segregated bus system that prompted the Freedom Rides of 1961. He recalled that at that time, "blacks and whites could not board a Greyhound bus together and travel from Virginia through North Carolina, South Carolina, Georgia, Alabama, Mississippi without the possibility of being arrested, jailed or beaten." By contrast, he described Obama's election as part of a "nonviolent revolution" that gave value to the civil rights struggle. He explained, "It was worth the pain, the suffering, the beatings, the jailing. I just wish some of the people like Martin Luther King Jr., Robert Kennedy, President Kennedy, Lyndon Johnson, and many other people that started on the journey and never made it, I wish they were here to bear witness."77 This anecdote's emphasis on outward physical manifestations of racial hatred reinforces individualist interpretations of racism that belie the systemic dimensions of racial injustice and place racism in the past. Lewis's recollections of civil rights traumas also functions as a foil for harmonized race relations epitomized by Obama's election. By framing Lewis's physical injury and violation as a means to achieve Obama's election, NBC positions Obama's success as a civil rights legacy.

Lewis was among several individuals featured by the mainstream press to highlight the violence that black activists faced during the civil rights movement. The focus on physical injury and loss across many news fragments contributed to a transcendent narrative in which Obama's election overcomes the traumatic memory of civil rights struggles. These fragments exemplify Kenneth Burke's conceptualization of transcendence as a rhetorical process of overcoming social violation. As Steven Goldzwig explains, transcendence is "a 
means of advancing a 'purified perspective' on events and circumstances in a direct effort to overcome symbolically perceived negative manifestations."78 Across many reports on the inauguration, Obama's election is positioned as the purifying agent that negates the legacy of physical injury and loss incurred during the civil rights era.

In one of few commemorative pieces that did not feature Martin Luther King, Bob Herbert observed Obama's election by describing attacks on James Farmer during his voting drive in Louisiana in 1963. During an interview with Herbert before his death in 1999, Farmer stated that he believed he "was meant to die" during those attacks. "They were kicking open doors, beating up blacks in the streets, interrogating them with electric cattle prods." Herbert followed his narrative by asking readers to imagine how Farmer and other civil rights leaders might have conversed with one another during the inauguration, "Imagine the stories and the mutual teasing and the laughter, and the deep emotion that would accompany their attempts to rise above their collective disbelief at the astonishing changes they did so much to bring about." Herbert concluded, "It's so easy, now that the moronic face of racism is so seldom openly displayed, to forget how far we've really come."79 In one reaction quote, an unidentified woman described vague memories of her experiences with racism and struggle. Speaking to $\mathrm{CNN}$ reporters, she asserted, "This really is a dream come true. Because, for one thing, you remember the hurt. You remember when people couldn't walk together. It was-it's like I didn't think I would live to see this coming." 80 The allusions to the pain of segregation and violent repression against former civil rights protesters in these examples gave urgency to narratives of racial struggle that find resolution in Obama's election. In this way, coverage of the election invokes a sense of symbolic closure to the civil rights era.

By focusing on Southern repression that occurred prior to the Black Power movement's agitation for economic justice, these allusions also place the brutality of racial discrimination in the past. Popular discourses surrounding the election that consign physical violation against the black community to the civil rights era illuminates how national memory continues to obscure the ongoing vulnerability of black bodies in public spaces. In her poignant analysis, Elizabeth Alexander argues that popular culture's portrayal of the black masculine body is constitutive of the African American community's traumatized historic collective memory. Alexander explains that historic images of violence against black men, including numerous slaves, Emmett Till, and Rodney King, remind black communities of their constant state of physical vulnerability. She suggests that white-authored national narratives have obscured this memory and concludes that

the American way with regard to the actual lived experience of African Americans has been to write a counternarrative which erased bodily information as we knew it and substituted a countertext which in many cases has become a version of national memory. ${ }^{81}$

Paradoxically, news media discourse surrounding the Obama presidency draws upon the collective memory that Alexander writes about in ways that rupture continuity with the present. The simultaneous acknowledgment and erasure of traumatic black experience from the civil rights era across this fragmented discourse illustrates how selective amnesia 
surrounding black activism is often underwritten through oblique references to contentious events that, if elaborated, would disconfirm narrative resolution in the present. Several comments connecting King's 1963 speech to Obama's 2009 inauguration briefly alluded to King's assassination and the urban riots that followed. ${ }^{82}$ Former civil rights activist Barbara Williams Emerson told PBS reporters that Obama's inauguration made her feel like African Americans had "come full circle." She explained that she had attended the March on Washington, the "greatest day up to now," and that she had been working on King's Poor People's Campaign when King was shot. She concluded her remarks by stating, "I think that was the saddest day for us, and I think today is the happiest day, and I'm just very proud to be here." 83 Emerson's remarks evince the idea of a return to a nostalgic civil rights past imbued with sentiments of promise that had been darkened by the tragedy of King's death and the unfulfilled goals of the Poor People's Campaign. Stated in the context of Obama's election as the "happiest" day for civil rights, the reference encourages audiences to find satisfaction and redemption from civil rights' trauma in the election of an African American president. Ostensibly, days of racial anguish have been left in the past.

CNN extended particular effort to articulate a narrative of national transcendence in a two-and-a-half-minute video directed by Antoine Fuqua entitled From MLK to Today. The network aired this video at 7:00 and 10:00 pm EST on Martin Luther King Day. ${ }^{84}$ In the video, Fuqua edits sound recordings of two of Obama's campaign speeches with video footage of several civil rights protests, King's 1963 speech at the March on Washington, and Obama's Presidential Nomination acceptance during the DNC in Denver, Colorado, on August 28, 2008. The film begins with footage of King and other civil rights activists marching across the Edmund Pettus Bridge in Selma, Alabama, accompanied by voiceover remarks from Obama's address to the NAACP convention in Cincinnati, Ohio, on July 14, 2008: "Dr. Martin Luther King Jr. was but 26 years old when he led a bus boycott to Montgomery to mobilize the movement." The video continues with a sequence of iconic images of the civil rights struggle including scenes of police beating protesters with clubs, King's arrest in Birmingham, water jets turned on black children, and King standing outside his hotel room in Memphis where he was assassinated. As the video presents these images, Obama's voice reminds audiences of "the debt that we all owe to those who marched forth and fought for us and stood up on our behalf. The sacrifices were made by those we never knew, those giants whose shoulders we stand on here today."

The last minute of the video cuts back and forth between footage of King's 1963 speech at the March on Washington and Obama's speech in Denver. Voiceover from Obama's acceptance speech connects King's speech to Obama's sentiments about the "the American promise" that inspired social change and national unity. Rapid crosscutting of footage from these events creates a montage effect in which the crowds at each event look almost indistinguishable; likewise, the long shots of King and Obama facing the sea of people draw visual comparisons between the two men. The effect is to conflate the two moments in time, thus aligning King's 1963 vision with Obama's success. Soledad O'Brien states this point explicitly during CNN's coverage of the inauguration ceremony, "I think there is a sense of history again, and a direct line from the work that was done, from the associates of Martin Luther King and Dr. King himself, to today." 85 The voiceover taken from Obama's 
speech in Denver ascribes meaning to the last montage of images by linking agitation for civil rights during the March on Washington to Obama's call for political unity at the start of his national campaign. The video closes with the conclusion of Obama's acceptance speech, "In America, our destiny is inextricably linked. . . . Together our dreams can be one."

Fuqua's selection of Obama's oratory parallels the selective uses of King's speech in other fragments responding to the election. During his NAACP address, Obama condemned the unequal distribution of wealth in the United States and advocated corporate reforms to end unfair labor practices. ${ }^{86}$ By selecting only the first few lines of this speech, Fuqua aligns Obama's rhetoric with the postracial framing of the election as the conclusion to the civil rights struggle. From MLK to Today illustrates how the fragmented discourses of popular media recontextualized political discourses to present Obama's election within a narrative of racial transcendence. It also illustrates how the fragmented discourses fused the reductionist narrative of King's "dream" with a similar reductionist narrative of Obama's own political vision.

\section{Selective Amnesia in Obama: The Dream Fulfilled}

These reductionist narratives were amplified by news media discourses that more directly positioned Obama's election as the latest among historical accomplishments of African Americans. During the month between the election and inauguration, several reports provided short chronologies of civil rights achievements. The Washington Post provided a short chronology of Martin Luther King's childhood;"87 CBS reported a list of civil rights pioneers including Nat King Cole and Sidney Poitier; ${ }^{88}$ and NBC's Dateline interviewed black activists and celebrities including John Legend and Ruby Dee who recounted historic racial injustices that occurred from the period of slavery until the passage of the Voting Rights Act. ${ }^{89}$ Aside from CBS's reference to Poitier's performance in the 1967 motion picture Guess Who's Coming to Dinner, none of these reports acknowledged events that took place in the years between 1965 and Obama's election; nor did they acknowledge black leaders who critiqued the limitations of civil rights programs for achieving racial and economic justice. One exception was ABC's Good Morning America segment that acknowledged Stokely Carmichael in its list of important quotes from racial justice advocates. ${ }^{90}$ The virtually absent references to black dissent after 1965 in coverage commemorating black achievements illustrate how selective amnesia is enacted through routine omission of public figures who have offered radical critiques of systemic injustices.

A vivid and extended example of selective amnesia in news media texts commemorating Obama's inauguration is a historical retrospective magazine entitled Obama: The Dream Fulfilled..$^{91}$ This magazine, published by Multi Media International (MMI), sold in retail stores nationwide in the weeks after Obama's election, including Wal-Mart, Kroger grocery stores, CVS pharmacies, and Barnes and Noble bookstores. ${ }^{92}$ (I purchased a copy of the magazine at the Atlanta Hartsfield-Jackson Airport.) One hundred and fourteen pages long, this special issue chronicles Obama's inauguration in the context of the "hard struggle for equality in the United States." ${ }^{\prime 93}$ The magazine opens with the statement that, 
With the election of the United States' first black president in Barak Obama, it's clear that the Dream of Dr. King has come a long way. While bigotry and ignorance may still exist, America has now, more than ever before, perhaps faster than anyone thought, fulfilled its promise as the land of opportunity. ${ }^{94}$

Primarily a photographic retrospective, the magazine chronicles events in the history of black struggle and the "rise of influential African Americans" in US history. ${ }^{95}$ Large 6" by 9" photographs depict central events in black history, including Jesse Owens' achievements at the 1936 summer Olympics in Berlin, Jackie Robinson's breaking the color barrier in baseball in 1947, and Rosa Parks's arrest for refusing to give up her seat in a Montgomery bus in 1955. The majority of the images leading up to those of Obama's inauguration feature Martin Luther King's efforts in the movement including the Montgomery Bus boycott, the Albany protests, and King's arrest in Birmingham. This magazine provides a richer narrative of national progress than most print dailies and broadcast journalism reports; however, arrangement and selection processes in the magazine ultimately reinforce the routine negation racial justice struggles following King's death.

The magazine's text and layout assert a close connection between King and Obama as the two central figures in the civil rights struggle. Reinforcing mainstream journalism's tendency to foreground the 1963 March for Jobs and Freedom, the magazine dedicates ten pages to King's speech at the march, which is the most prominently featured event aside from the coverage of Obama's campaign. Excerpts from King's speech appear in large bold print alongside photographs of King speaking before the large audience at the Washington Mall. The text in largest font quotes oft-cited sentences from the speech in which King envisions "his four little children will one day live in a nation where they will not be judged by the color their skin but by the content of their character" and "that one day this nation will live out the true meaning of its creed: We hold these truths to be self-evident: that all men are created equal." 96 Editorial print next to these excerpts asserts that in the context of Obama's election, these excerpts "could be called nothing less than prescient." 97

The retrospective diverges from its chronological ordering of events on page 58, after its commemoration of King's assassination. Following a photograph of mourners gathered for several blocks outside of the Ebenezer Baptist church to pay their respects to Dr. King, the magazine displays a close up image of Obama's profile, taking two full consecutive pages - larger than any other photographic image in the magazine. Implied by this layout of images is a visual enthymeme: President Obama is the final achievement of the project that was cut short by Martin Luther King's untimely death in 1968.

The magazine's cover also sutures King's memory to Obama's election. It depicts a black and white photograph of King gesturing toward an unseen audience transposed behind a much larger close-up image of Obama's face. Obama looks wistfully in the distance with his hands folded underneath his chin. The position of these images creates the illusion that King is pointing toward Obama. Although the contrasting quality of each figure makes it clear that the images are asynchronous, the visual arrangement gives King and Obama rhetorical continuity. 
Obama: The Dream Fulfilled offers hazy details about King's activism after his 1963 speech. In a two-paragraph section entitled, "Stance on Compensation," the retrospective magazine mentions that King advocated a program of financial compensation to disadvantaged groups including Native Americans. ${ }^{98}$ As an extended commemorative text, this magazine goes farther than most media sources to give context and nuance to the history of civil rights. References to King's advocacy of economic justice point to spaces in popular culture for counter-memory; ${ }^{99}$ however, such spaces are confined by the magazine's broader framework. Although these paragraphs acknowledge King's stance on compensation for blacks' history of injustice and the Poor People's Movement, it does not mention his opposition to the Vietnam War or his support for the sanitation workers' strike that brought him to Memphis when he was shot. Brief mention of King's struggles against conditions of poverty alludes to the conflicts that persisted after King's 1963 vision of a just society, but the magazine provides no cues that criticisms of economic injustice survived King.

The magazine's negation of tensions and conflicts within the racial justice movement constructs a narrative of racial struggle in the United States that finds its resolution in the Obama presidency. The retrospective concludes its history of the 1960s with King's assassination. Attention to race relations in the 1970s and 1980s is truncated in four pages and is followed by pages 66 through 114 that chronicle President Obama's emergence as a political figure leading up to election night. Missing altogether from this magazine's almost 60-year retrospective of the history of racial struggle and black achievement are references to other contentious but nonetheless pivotal figures in the history of racial struggle during the later years of civil rights including Fannie Lou Hamer, Stokely Carmichael, Huey Newton, and Bobby Seale. Malcolm X is mentioned once, but only to explain how Alex Haley became a successful author prior to his publication of Roots in 1976. As another case in point, pages 62 and 63 feature Muhammad Ali's prominence as a successful black boxer, but they do not mention how his conversion to the Nation of Islam was itself a statement of black resistance to dominant white cultural constructions of black identity in the United States.

These omissions exemplify how the rhetorical suturing of King's 1963 dream with Obama's election depended on the negation of a more complex history of black activism in the United States. The retrospective's final sentence concludes that "Barack Obama's ascendance into the role of the President of the United States of America has fulfilled the ideal that anyone of any race can rise up and make their dreams come true."100 By deleting black radicalism from the chronology of black activism in public memory, Obama: the Dream Fulfilled frames Obama's election as the completion of America's postracial transformation.

\section{Critical Rhetoric and the Resources for Counter-Memory}

Reinforcing popular discourses in broadcast and print media, Obama: The Dream Fulfilled contributes to selective amnesia that has repressed public memories of confrontational protest. The processes of selection and omission in news coverage of Obama's election illustrate how narratives of transcendence bypass significant moments in histories of social and 
political struggle. Selective amnesia refers to the omission of events that would dramatically reframe our understanding of how historic conflicts connect to contemporary social relations were they explicitly included within mainstream public discourse. A further look at the history negated by the transcendent narrative surrounding Obama's inauguration illuminates the important contexts that shed light on King's own significance for race relations. Histories of radicalism in the racial justice movement and expressions of black political rage are intertwined with the legacy of Martin Luther King's own activism. Houston Baker argues that King marks the segue from civil rights to Black Power because he remained committed to the expressed interests of the black majority who did not reap material rewards from early civil rights initiatives. ${ }^{101}$ Widespread urban riots in response to King's death were fomented by black communities' deep dissatisfaction and frustration with Johnson's Great Society programs meant to alleviate the harshest conditions of endemic poverty in the United States. As historian Clay Risen notes, it was in the cities where political leaders failed to reach out to their local black constituents where riots in the wake of King's assassination were most volatile. ${ }^{102}$ Articulations of black political anger may be understood as a response to the failures of King's 1963 vision that had once seemed to hold promise for many black communities.

King's own influence among moderate whites also is intertwined with black radicalism during the 1960s. King's positive image in mainstream media developed alongside the emergence of more militant black advocates such as Malcolm X. The white establishment considered King as a palatable alternative to X; however, King himself had been regarded as a radical by moderate democrats prior to 1963. King's role to inspire social change and more progressive attitudes about race was part and parcel with the role of more confrontational activists who have been largely forgotten in public memory. ${ }^{103}$ Thus, omissions and negations of histories of black militancy during Obama's inauguration are not merely those events that occurred on the peripheries of mainstream black activism but nurtured and reinforced King's efforts to achieve racial justice. The silence surrounding that perplexing sequence of traumatic events omits what is nonetheless central to understanding the evolution of civil rights activism in American history and the current state of race relations.

Further, such silence also negates contemporary activists who have continued to find inspiration from the legacies of King, Malcolm X, and others who have agitated for racial justice. Third Personae negated in this myth include black figures including Malcolm X, Stokely Carmichael, and Black Panther Party members who challenged King's rhetoric of nonviolent civil disobedience in favor of more direct confrontation with racial injustice. Also elided in this narrative are the goals that united Black Power activists and King's movement, particularly in the last years of King's life. By ignoring such goals as economic parity and the end to imperialistic wars, the narrative of transcendence surrounding Obama's inauguration crafts a thin version of civil rights that hollows out its radical potential. Attending to selective amnesia in news discourses surrounding the election illustrates how mainstream media have obscured broader histories of social struggle and denies contemporary activism of its rich heritage.

The routine omission of radical black dissent foregrounds the importance of distinguishing between absence that is inevitable in any commemoration of the past and absence 
that negates our deep histories of social injustice. More than elide conflict that threatens to disrupt national identity and celebration, these processes also foreclose opportunities for understanding US histories of social movements and the role of collective dissent within a democracy. The intertextual construction of selective amnesia in popular discourse may inform how contemporary publics respond to ongoing social conflicts and historic abuses of power. The production of amnesia thus impedes upon broader understanding of evolution and change within a political movement, legitimating other mainstream discourses that characterize communities and organizations seeking radical social transformation as out of touch, irrational, or corrupt.

Conditions of racial inequity that prompted radical black dissent remain unresolved. By forgetting those who have struggled against structural racism and its attendant violence against black communities in the United States, selective amnesia fosters conditions for a traumatic future for race relations. Critical geographer Joshua F. J. Inwood points out that

as local, state, and national officials celebrate and memorialize the victories of the US civil rights struggle, there has been a rolling back of civil rights legislation, and economic and racial discrimination persists and by some measures is growing more pronounced. ${ }^{104}$

A deeper understanding of our nation's own rich history of contentious activism may enable us to understand the implications of postracial policies. Richer depictions of dissent may also offer resources of counter-memory which point to continuities between historic and contemporary race relations. Such connections might then lead to the kind of work that needs to be done to prevent the routine occurrence of racial discrimination.

Were public memories of racial struggle to include the criticisms of structural racism articulated by Malcolm X, Stokely Carmichael, Fannie Lou Hamer, Angela Davis, or King in his later years, public deliberation might draw stronger connections between seemingly disconnected instances of racial injustice, such as the arrest of Henry Louis Gates in 2009, the stiff sentences meted out the Jena 6 in Louisiana in 2007, the devastation of New Orleans' 9th Ward after Hurricane Katrina in 2005, and the thousands of civilian casualties resulting from ongoing US military presence in Iraq and Afghanistan. Rather than attend to these issues as isolated examples of failed policy decisions or inept individuals, public discourse might attend to how these events are the outcome of an economic and political system that has operated through the global exclusion and exploitation of people of color and of lower class status. Although many New Orleans neighborhoods have been rebuilt, the 9th Ward is still in ruins. This disparity is largely the result of inequities in governmentsubsidized house reconstruction grants that have predominantly aided white Katrina victims. The ongoing devastation of the 9th Ward highlights the tragic consequences of structural racism. As such, it is a contemporary manifestation of economic injustice that prompted Stokely Carmichael to promote coalitions that might destroy the "basic institutions that perpetuate racism." 105

By exploring the discursive structures that uphold selective amnesia, critical rhetoric might offer its own form of resistance to the perils of forgetting historic injustice. Critical attention to amnesia reflects a commitment to scholarship that gives presence to under- 
resourced communities who have been routinely silenced in discourse and ignored by public policy. As a counterpart to critical memory scholarship that foregrounds voices of dissent, a critical rhetoric attendant to the discursive processes by which public amnesia is constructed may help to enrich our resources for envisioning social change and the means of attaining social justice. Critical rhetorical work on memory and forgetting thus provides textual resources for those of us who are dissatisfied with national and global power relations to consider ourselves as part of a broader and ongoing movement.

Acknowledgments - The author wishes to thank Raymie McKerrow, Victoria Gallagher, Jonathan Rossing, Bryan McCann, and anonymous reviewers for their insightful commentary and suggestions. She is also grateful for Casey Kelly's encouragement and thoughtful criticism throughout the writing process. An earlier version of this manuscript was presented at the 2009 National Communication Association conference in Chicago.

\section{Notes}

[1] Barack Obama, The Audacity of Hope: Thoughts on Reclaiming the American Dream (New York: Vintage Books, 2006), 40.

[2] Barack Obama, “A More Perfect Union-March 18, 2008." American Rhetoric Online Speech Bank, http://www.americanrhetoric.com/speeches/barackobamaperfectunion.htm.

[3] Dan Balz and Haynes Johnson, "A Political Odyssey; How Obama's Team Forged a Path That Surprised Everyone, Even the Candidate," The Washington Post, August 2, 2009.

[4] Peniel Joseph, Dark Days, Bright Nights: From Black Power to Barack Obama (New York: Basic Books, 2010).

[5] Jill Edy, “Journalistic Uses of Collective Memory," Journal of Communication 49 (1999): 71-87.

[6] Early and fundamental essays within the discipline include Carole Blair, Marsha S. Jeppeson, and Enrico Pucci Jr., "Public Memorializing in Postmodernity: The Vietnam Veterans Memorial as Prototype," Quarterly Journal of Speech 77 (1991): 263-88; Stephen H. Browne, "Reading Public Memory in Daniel Webster's Plymouth Rock Oration," Western Journal of Communication 57 (1993): 464-77; Stephen H. Browne, "Remembering Crispus Attucks: Race, Rhetoric, and the Politics of Commemoration," Quarterly Journal of Speech 85 (1999): 169-87; and Bruce Gronbeck, "The Rhetorics of the Past: History, Argument, and Collective Memory," in Doing Rhetorical History: Concepts and Cases, ed. Kathleen J. Turner (Tuscaloosa: University of Alabama Press, 1998), 47-60. For recent examples, see Kendall Phillips, ed. Framing Public Memory (Tuscaloosa: University of Alabama Press, 2004); and Greg Dickinson, Brian L. Ott, and Eric Aoki, "Spaces of Remembering and Forgetting: The Reverent Eye/I at the Plains Indian Museum," Communication and Critical/Cultural Studies 3 (2006): 27-47.

[7] John Bodnar, Remaking America: Public Memory, Commemoration, and Patriotism in the Twentieth Century (Princeton, N. J.: Princeton University Press, 1992), 15.

[8] Stephen Browne, "Review Essay: Reading, Rhetoric, and the Texture of Public Memory," Quarterly Journal of Speech 81 (1995): 237-65.

[9] Pierre Nora, “Between Memory and History: Les Lieux de Memoire," Representations 26 (1989): 7-24.

[10] Michael Kammen, Mystic Chords of Memory: The Transformation of Tradition in American Culture (New York: Knopf, 1991), 3; Barbara Biesecker, "Remembering World War II: The Rhetoric 
and Politics of National Commemoration at the Turn of the 21st Century," Quarterly Journal of Speech 88 (2002): 406.

[11] Biesecker, "Remembering"; Dickinson, Ott, and Aoki, "Spaces"; Kristen Hoerl, "Mario Van Peebles's 'Panther' and Popular Memories of the Black Panther Party," Critical Studies in Media Communication 24 (2007): 206-27; Kristen Hoerl, "Burning Mississippi into Memory? Cinematic Amnesia as a Resource for Remembering Civil Rights," Critical Studies in Media Communication 26 (2009): 54-79; Roseann M. Mandziuk, "Commemorating Sojourner Truth: Negotiating the Politics of Race and Gender in the Spaces of Public Memory," Western Journal of Communication 67 (2003): 271-91.

[12] Browne, “Reading Public Memory," 466.

[13] Browne, "Remembering Crispus Attucks"; Mandziuk, "Commemorating."

[14] Victoria J. Gallagher, "Memory and Reconciliation in the Birmingham Civil Rights Institute," Rhetoric and Public Affairs 2 (1999): 303-20.

[15] Denise M. Bostdorff and Steven R. Goldzwig, "History, Collective Memory, and the Appropriation of Martin Luther King, Jr.: Reagan's Rhetorical Legacy," Presidential Studies Quarterly 35 (2005): 661-90; Shawn J. Parry-Giles and Trevor Parry-Giles, "Collective Memory, Political Nostalgia, and the Rhetorical Presidency: Bill Clinton's Commemoration of the March on Washington August 28, 1998," Quarterly Journal of Speech 86 (2000): 417-37.

[16] Marouf Hasian Jr. and A. Cheree Carlson, "Revisionism and Collective Memory: The Struggle for Meaning in the Amistad Affair," Communication Monographs 67 (2000): 42-62; Kelly J. Madison, "Legitimation Crisis and Containment: The 'Anti-Racist-White-Hero' Film," Critical Studies in Media Communication 16 (1999): 399-416; and Kristen Hoerl, "Mississippi's Social Transformation in Public Memories of the Trial Against Byron de la Beckwith for the Murder of Medgar Evers," Western Journal of Communication 72 (2008): 62-82.

[17] Other essays have suggested that civil rights museums provide productive spaces for transcending social differences and resisting racial injustice. See Victoria J. Gallagher, "Remembering Together? Rhetorical Integration and the Case of the Martin Luther King, Jr. Memorial," Southern Communication Journal 60 (1995): 109-19; and Carole Blair and Neil Michel, "Reproducing Civil Rights Tactics: The Rhetorical Performances of the Civil Rights Memorial," Rhetoric Society Quarterly 30 (2000): 31-55.

[18] Gallagher, "Memory."

[19] Bostdorff and Goldzwig, "History"; Parry-Giles and Parry-Giles, "Collective Memory."

[20] Kirt H. Wilson, "Rhetoric and Race in the American Experience: The Promises and Perils of Sentimental Memory," in Sizing Up Rhetoric, ed. David Zarefsky and Elizabeth Benacka (Long Grove, IL: Waveland Press, 2008), 20-39.

[21] Marita Sturken, Tangled Memories: The Vietnam War, the AIDS Epidemic, and the Politics of Remembering (Berkeley: University of California Press, 1997); Barbie Zelizer, Remembering to Forget: Holocaust Memory through the Camera's Eye (Chicago: The University of Chicago Press, 1998).

[22] Bradford Vivian, "Review Essay: On the Language of Forgetting," Quarterly Journal of Speech 95 (2009): 89-104.

[23] Bradford Vivian, Public Forgetting: The Rhetoric and Politics of Beginning Again (University Park: Pennsylvania State University Press, 2010).

[24] Kammen, Mystic, 13.

[25] Raymie E. McKerrow, "Critical Rhetoric: Theory and Practice," Communication Monographs 56 (1989): 107. 
[26] Robert L. Scott, "Dialectical Tensions of Speaking and Silence," Quarterly Journal of Speech 79 (1993): 14.

[27] Dana L. Cloud, "The Null Persona: Race and the Rhetoric of Silence in the Uprising of '34," Rhetoric and Public Affairs 2 (1999): 177-209; Carrie Crenshaw, "Resisting Whiteness' Rhetorical Silence," Western Journal of Communication 61 (1997): 253-78.

[28] Philip C. Wander, "The Third Persona: An Ideological Turn in Rhetorical Theory," Central States Speech Journal 35 (1984): 210.

[29] Wander, "The Third," 210.

[30] Kenneth Burke, Attitudes Toward History, 3rd ed. (Berkeley: University of California Press, 1984), 80.

[31] James P. Zappen, "Kenneth Burke on Dialectical-Rhetorical Transcendence," Philosophy and Rhetoric 42 (2009): 297.

[32] Kenneth Burke, Language as Symbolic Action: Essays on Life, Literature, and Method (Berkeley: University of California Press, 1966), 187.

[33] Parry-Giles \& Parry-Giles, "Collective Memory," 418.

[34] CNN, "Inauguration Day Coverage," CNN Live Event Special, January 20, 2009.

[35] Kenneth T. Walsh, "For Obama's Inauguration, Echoes of Lincoln and Martin Luther King," US News.com, January 16, 2009.

[36] PBS, "Barack Obama Inaugurated as 44th President of the United States," The News Hour with Jim Lehrer, January 20, 2009; CNN, "National Mall Filling Early for Obama Inauguration Day," American Morning, January 20, 2009.

[37] PBS, "Congressman, Journalists Reflect on the Presidency on Eve of Obama's Inauguration," The Charlie Rose Show, January 19, 2009 and Fox, "More Inauguration Coverage," Live Event, 10:00 AM EST, January 20, 2009.

[38] See also CNN, "Final Preps at Inaugural Site; Secret Service Countersnipers; 'A Dream Come True'; Changing Views of Obama," The Situation Room, January 19, 2009; Barbara Boxer, "My Inaugural Reflections," Huffington Post. January 22, 2009, http://www.huffingtonpost.com; NBC, "Professor Michael Eric Dyson Discusses This Historic Inauguration Day in the Context of Dr. King and Struggle for Civil Rights," Today Show, January 20, 2009; and MSNBC, [untitled], MSNBC Special, 1:00 EST, January 20, 2009.

[39] MSNBC, "For January 19, 2009," 1600 Pennsylvania Avenue with David Gregory, January 19, 2009.

[40] FOX, "America Prepares for the Transfer of Presidential Power," On the Record with Greta Van Susteren, January 19, 2009. For a similar example see FOX, “Special Edition: Obama's Inauguration," The O'Reilly Factor, January 20, 2009.

[41] NBC, "This Moment, This Time," Dateline, January 18, 2009.

[42] CNN, "Inauguration Day Coverage," CNN Live Event Special 3:00 EST, January 20, 2009.

[43] FOX, "Preparations for the Inauguration Continue," The O'Reilly Factor, January 18, 2009.

[44] ABC, "Witness to History: Historic Pilgrimage," Good Morning America, January 18, 2009.

[45] Rachel L. Swarns, "Vaulting the Racial Divide, Obama Persuaded Americans to Follow," New York Times, November 5, 2008.

[46] Judy Keen, "Many See Dream Come True; They Plan Trips to D.C. for Obama's Inauguration If Only to Be Near to the Man Whose Success Touched Them," USA Today, November 28, 2008. 
[47] NBC, "People from All Backgrounds at Inaugural Ceremony," NBC Nightly News, January 20, 2009.

[48] "And Now," 2009

[49] This selection of artifacts for analysis works in accordance with Michael McGee's observation that the first job of the critical rhetorician is to "[invent] a text suitable for criticism" out of the available scraps and pieces of evidence within our fractured media environment. See Michael Calvin McGee, "Text, Context, and the Fragmentation of Contemporary Culture," Western Journal of Speech Communication 54 (1990): 288. For a discussion of media constraints on interpretation, see also Celeste Michelle Condit, "The Rhetorical Limits of Polysemy," Critical Studies in Mass Communication 6 (1989): 103-22.

[50] Raymie McKerrow, "Critical Rhetoric and the Possibility of the Subject," in The Critical Turn: Rhetoric and Philosophy in Postmodern Discourse, ed. Ian Angus and Lenore Langsdorf (Carbondale and Edwardsville: Southern Illinois University Press, 1993): 51-67.

[51] Eduardo Bonilla-Silva, Racism without Racists: Color-blind Racism and the Persistence of Racial Inequality in America (Lanham, MD: Rowman \& Littlefield, 2009).

[52] CNN, "National Mall."

[53] Mary Mitchell, “It Wasn't Easy: King's Prophetic Dream, Decades in the Making, Takes a Giant Leap as He Passes the Torch to Illinois' Favorite Son," Chicago Sun-Times, January 19, 2009.

[54] Walter R. Fisher, "Reaffirmation and Subversion of the American Dream," Quarterly Journal of Speech 59 (1973): 160-67.

[55] Bostdorff and Goldzwig, "History"; Dana L. Cloud, "Hegemony or Concordance? The Rhetoric of Tokenism in 'Oprah' Winfrey's Rags-to-Riches Biography," Critical Studies in Mass Communication 13 (1996): 115-37; Kristen Hoerl, "Cinematic Jujitsu: Resisting White Hegemony Through the American Dream in Spike Lee's Malcolm X," Communication Studies 59 (2008): 355-70.

[56] Catherine Squires, Eric King Watts, Mary Douglas Vavrus, Kent A. Ono, Kathleen Feyh, Bernadette Marie Calafell, Daniel C. Brouwer, "What is this 'Post' in Postracial, Postfeminist .. . (Fill in the Blank)?" Journal of Communication Inquiry 34 (2010): 210-53.

[57] Andrew Young, “Week One of a Dream Fulfilled," Los Angeles Times, January 26, 2009.

[58] CNN, "Final Preps."

[59] CNN, “Martin Luther King's Dream," Anderson Cooper 360 Degrees, January 19, 2009.

[60] CBS, "Memorable Sights and Sounds from Inaugural Day," CBS Evening News, January 20, 2009; CNN, “Inauguration Day Coverage," Live Event Special 11:00 EST, January 20, 2009; FOX, “Continuing Coverage of Inauguration Day Events," Live Event, 11:00 EST, January 20, 2009; PBS, “Barack Obama”; MSNBC, “Inauguration Coverage," MSNBC Special, 12:00 EST, January 20, 2009.

[61] Barack Obama, "Pre-Inauguration Address at the Lincoln Memorial-January 18, 2009," American Rhetoric Online Speech Bank, http://www.americanrhetoric.com/speeches/barackobama/ barackobamapreinaugurallincolnmemorial.htm.

[62] Barack Obama, "Presidential Inaugural Address: What Is Required: The Price and the Promise of Citizenship-January 20, 2009," American Rhetoric Online Speech Bank, http://www.american rhetoric.com/speeches/barackobama/barackobamainauguraladdress.htm.

[63] Swarns, "Vaulting the Racial Divide."

[64] CNN, "Martin Luther King's Dream"; FOX, "Dr. King's Legacy," FOX Special Report with Brit Hume, January 19, 2009. 
[65] CNN, "Martin Luther King's Dream."

[66] CNN, "Inauguration Eve," CNN Larry King Live, January 19, 2009; Rick Hampson, Larry Copeland, Charisse Jones, and William M. Welch, "Where King Preached, Obama's the Word; Sunday Sermons See a Dream Fulfilled, but More to be Done," USA Today, January 19, 2009; NBC, “Obama's Inauguration Day and Other Topics," Meet the Press, January 18, 2009.

[67] CNN, "Coverage of Pre-Inauguration Events," CNN Live Event Special 3:00 EST, January 18, 2009.

[68] CNN, "Coverage of Pre-Inauguration Events."

[69] CNN, "From MLK to Today," CNN Live Event Special 7:00 EST, January 19, 2009.

[70] Bostdorf and Goldzwig, "History."

[71] Derrick P. Alridge, "The Limits of Master Narratives in History Text Books: An Analysis of Representations of Martin Luther King, Jr.," Teacher's College Record 108 (2006): 662-86.

[72] For a discussion of the nuances of King's rhetoric and philosophy in 1967 see George N. Dionisopoulos, Victoria J. Gallagher, Steven R. Goldzwig, and David Zarefsky, "Martin Luther King, the American Dream, and Vietnam: A Collision of Rhetorical Trajectories," Western Journal of Communication 56 (1992): 91-107.

[73] Gary Daynes, Making Villains, Making Heroes: Joseph R. McCarthy, Martin Luther King, Jr. and the Politics of American Memory (New York: Garland Publishing, 1997), 131.

[74] Eduardo Bonilla-Silva, White Supremacy and Racism in the Post-Civil Rights Era (Boulder, CO: Reiner, 2001); Andreana Clay. "All I Need Is One Mic": Mobilizing Youth for Social Change in the Post-Civil Rights Era. Social Justice 33 (2006): 105-21.

[75] Thomas L. Friedman, "Finishing Our Work," New York Times, November 5, 2008.

[76] CBS, "Mayor Cory Booker Discusses the Historical Significance of Barack Obama Being Elected President," The Early Show, January 19, 2009.

[77] NBC, "John Lewis, Last Surviving Speaker from Platform Where Martin Luther King Jr. Gave 'I Have a Dream' Speech, Will Be at Obama's Inauguration," Nightly News, January 19, 2009.

[78] Steven R. Goldzwig, "LBJ, the Rhetoric of Transcendence, and the Civil Rights Act of 1968," Rhetoric and Public Affairs 6 (2003): 41.

[79] Bob Herbert, “I Wish You Were Here," The New York Times, January 20, 2009.

[80] CNN, "Final Preps."

[81] Elizabeth Alexander, "Can you be BLACK and Look at This?" Reading the Rodney King Video(s)," in The Black Public Sphere Collective: A Public Culture Book, ed. The Black Public Sphere Collective (Chicago and London: University of Chicago Press, 1995), 84.

[82] ABC, "A New Day; Expectations," World News with Charles Gibson, November 5, 2008; Mitchell, "It Wasn't Easy"; Chao Xiong and Curt Brown, "The Inauguration of Barack Obama; Minnesota Reaction: 'Love and cooperation know no skin color'; For Those Around the Twin Cities who Watched Obama Take the Oath of Office, Optimism Reigned," Minneapolis Star Tribune, January 21, 2009; CNN, “The 'We Are One' Concert Set to Begin at Lincoln Memorial, Obama Family, Biden Family Arrive, Wide Array of Stars to Perform, Attend, Honoring Lincoln, King, Obama," CNN Live Event Special, 2:00 EST, January 18, 2009.

[83] PBS, "Barack Obama Inaugurated."

[84] CNN, "From MLK to Today"; CNN, "Whirlwind Day for Barack Obama," Anderson Cooper 360 Degrees 10:00 PM EST, January 19, 2009.

[85] CNN, “Inauguration Day Coverage," CNN Live Event Special, 10:00 AM EST, January 20, 2009. 
[86] Barack Obama, “Remarks to the NAACP Convention," Democratic Underground, July 14, 2008, http:// www.democraticunderground.com/discuss/duboard.php?az=view=all\&address=132x6501240.

[87] "Honoring Martin Luther King Jr., the Man and the Kid," The Washington Post, January 19, 2009.

[88] CBS, "Achievements in African-American History," The Early Show, January 1, 2009.

[89] NBC, "This Moment."

[90] ABC, "Inauguration of Barack Obama: Pioneers of the Civil Rights Movement," Good Morning America, January 19, 2009.

[91] Obama: The Dream Fulfilled, A Historical Retrospective. (Tinton Falls, NJ.: Multi-media International, 2009).

[92] “About Us," Multi-Media International, http://web.archive.org/web/20090626112520/, http://www .mmimags.com/magazines.html.

[93] Obama: The Dream Fulfilled, 3.

[94] Obama: The Dream Fulfilled, 3.

[95] Obama: The Dream Fulfilled, 3.

[96] Obama: The Dream Fulfilled, 42-43.

[97] Obama: The Dream Fulfilled, 43.

[98] Obama: The Dream Fulfilled, 46.

[99] For further discussion of counter-memory, see George Lipsitz, Time Passages: Collective Memory and American Popular Culture (Minneapolis: University of Minnesota Press, 1990).

[100] Obama: The Dream Fulfilled, 114.

[101] Houston Baker, "Critical Memory and the Black Public Sphere," reprinted in The Black Public Sphere Collective: A Public Culture Book (University of Chicago Press: Chicago, 1995), 7-37.

[102] Clay Risen, A Nation on Fire: America in the Wake of the King Assassination (Hoboken, NJ: Wiley, 2009).

[103] James H. Cone. Martin \& Malcolm X \& America: A Dream or a Nightmare (Maryknoll, NY: Orbis Books, 1997).

[104] Joshua F. J. Inwood, "Contested Memory in the Birthplace of a King: A Case Study of Auburn Avenue and the Martin Luther King Jr. National Park," Cultural Geographies, 16 (2009): 90.

[105] Stokely Carmichael, "Berkeley Speech, October 1966," reprinted in Dissent in America: The Voices That Shaped a Nation, ed. Ralph F. Young (New York: Pearson, 2006), 567-76. 